\title{
Szkolna kultura polityczna. Czym jest i jak ją badać?
}

\section{KEYWORDS}

school political culture, school culture, school as an organisation, civic competences

\begin{abstract}
Kamecka-Antczak Celina, Szkolna kultura polityczna. Czym jest i jak ją badać? [School political culture. What is it and how to study it?]. Kultura - Społeczeństwo - Edukacja nr 1(17) 2020, Poznań 2020, pp. 179-197, Adam Mickiewicz University Press. ISSN 2300-0422. DOI 10.14746/ kse.2020.17.9.1
\end{abstract}

The article is an attempt to create a new category in the study of the school, which is school political culture. Theoretical meta-analysis was used. In the first part, the author explains why she asks about school political culture. Based on the assumption that the school is an organisation, it justifies applying the tools of political culture to its study. The school as an organisation is a separate system of activity, with clearly defined goals, a specific division of labour among members of the school community and connectivity between elements with a certain degree of formalisation and hierarchy of power. A comparison of elements of the school's organisation with the basic elements of the political system is presented. The second part introduces the criteria that the theory of political culture should meet to become a theory that can be applied in school space. A meta-analysis of selected concepts of political culture: Gabriel Almond, Vilfredo Pareto and Zbigniew Blok (based on the developed criteria) allowed the selection of a leading theory. The results of meta-analysis are the subject of the third part of the article. The initial adaptation of the selected theory leading to the school specificity is a contribution to further scientific work on the development of a research tool allowing the classification of school political culture: of individual students, as well as the one dominating in the group.

\footnotetext{
* ORCID https://orcid.org/0000-0001-8476-9738.
} 


\section{Wprowadzenie}

Celem artykułu jest próba odpowiedzi na pytanie: czy kategorię kultury politycznej możemy zastosować do badania szkoły, a jeśli tak, to na jakiej koncepcji kultury politycznej się oprzeć? Pojęcia „szkoła” i „kultura polityczna” są niezwykle szerokie i trudne do precyzyjnego zdefiniowania. Termin „kultura polityczna” sam składa się z kolejnych dwóch trudno definiowalnych pojęć: „kultura” i „polityka”. Wprowadza to wiele wątpliwości i obaw, czy łączenie tych dwóch zagadnień nie sprowadzi badacza na manowce. Z pewnością zastosowanie uporządkowanego podejścia metodologicznego, jakim jest metaanaliza teoretyczna, pozwoli znacząco ograniczyć kłopoty z tym związane.

Kultura polityczna jest - w bardzo ogólnym ujęciu - zbiorem przekonań i działań uczestników danego systemu politycznego względem tego systemu. Jej zakres obejmuje idee, wartości, normy polityczne, nawyki, tradycje, wzory zachowań politycznych, emocje wobec faktów politycznych i kryteria ich oceny (Sarnacki, 2016). Klasyczne koncepcje kultury politycznej dotyczą poziomu państwowego, pytają o stosunek obywateli do elementów systemu politycznego danego państwa i determinanty tego stosunku. W zależności od koncepcji będziemy szukać przejawów kultury politycznej w wypowiedziach (por. Almond, Verba, 1963) i/lub działaniach (por. Blok, 2009) członków danej zorganizowanej politycznie społeczności. Determinantów kultury politycznej będziemy szukać w posiadanej przez jednostki wiedzy, wyznawanym przez nie systemie wartości czy właśnie w systemie organizacji państwa, wyznaczającym każdemu uczestnikowi realne pole działania. Niektóre koncepcje kultury politycznej biorą pod uwagę tylko systemy demokratyczne (por. Ferejohn, Rakove, Riley, 2001). Inne dają możliwość pytania o kulturę polityczną $\mathrm{w}$ różnych, także niedemokratycznych systemach. Wyznaczając cechy zachowań wzorowego obywatela, koncepcje kultury politycznej niekiedy mogą stawać się narzędziem politycznej indoktrynacji. Pytając o determinanty tych zachowań, mogą tworzyć wzory systemów idealnych. Kwestią sporną pozostaje wartościowanie typów kultury politycznej. Niektórzy autorzy (por. de Lazari, 2016) uznają za uzasadnione pytanie o istnienie kultury politycznej danej społeczności lub jej brak. Definiują oni kulturę polityczną jako kulturę jednostek wykazujących się obywatelską aktywnością.

Kulturę polityczną możemy badać całościowo jako dominującą w danym społeczeństwie oraz w danej grupie społecznej czy organizacji. Wówczas pytać możemy o kulturę polityczną pracowników danej korporacji czy studentów itp. Założonym celem mojej pracy jest poznanie szkolnej kultury politycznej i ustalenie sposobów jej badania. Przy czym pytam tu nie o dominującą kulturę polityczną 
uczniów względem polityki państwa, a o możliwość zastosowania koncepcji kultury politycznej w przestrzeni szkolnej. Pytam o kulturę polityczną zastaną w danej szkole i tworzoną względem jej własnej wewnętrznej organizacji. Zadaję pytanie: jak badać tak zdefiniowaną kulturę polityczną szkoły? Czy ideę kultury politycznej możemy zastosować do specyfiki szkolnej?

Interpretując szkołę w perspektywie organizacyjnej, można przyrównać ją do instytucji, która rządzi się własnymi prawami i regułami, wytwarza wspólny produkt oraz dotyczy ludzi połączonych więzami instytucjonalnymi (por. Dymara, 2009). Chcąc zrozumieć szkolną rzeczywistość, nie można odrywać jej od kultury ogólnej, której szkoła jest częścią, jak i pomijać faktu, że jako organizacja tworzy ona swoją własną kulturę wewnętrzną, którą zastajemy, wchodząc do szkoły (Dernowska, Tłuściak-Deliowska, 2015). Zastosowanie do badania szkoły optyki kultury politycznej wymaga postawienia pytań: Czy szkoła jest zorganizowana politycznie? Czy system zarządzania nią (jako organizacją) zbliżony jest do systemu politycznego, służącego zarządzaniu państwem? Szukając odpowiedzi na te pytania, przyjrzano się podstawowym elementom systemu politycznego (por. Zieliński, 1999; Podolak, Żmigrodzki, 2013) i spróbowano odnaleźć je w systemie organizacji szkoły:

1) współzależna społeczność, składająca się z grup o interesach zbieżnych i sprzecznych - szkolna społeczność ma wspólne cele, składa się z tak zwanych grup o interesach zbieżnych i sprzecznych, takich jak chociażby uczniowie, rodzice, nauczyciele, z których każda może być dodatkowo wewnętrznie złożona;

2) organizacje, które poprzez wywieranie wpływu oraz zdobywanie i sprawowanie władzy reprezentują interesy tych grup - w szkole rolę tę odgrywają przedstawiciele samorządu uczniowskiego, rada rodziców, rada szkoły, a także na przykład koła aktywności pozalekcyjnej;

3) instytucje władzy państwowej mające monopol uwzględniania interesów grupowych, dysponujące zarówno narzędziami perswazji, jak i przymusu oraz przemocy - tym elementem będzie dyrekcja szkoły, rada pedagogiczna(?);

4) normy formalne i zwyczajowe regulujące wzajemne relacje i funkcjonowanie wszystkich części składowych systemu oraz ideologie i strategie polityczne - w przypadku szkół będą to normy ustalane zewnętrznie w rozporządzeniach właściwego ministra oraz normy wewnętrzne zawarte w statucie szkoły i innych wewnątrzszkolnych aktach prawnych;

5) instytucje i organizacje międzynarodowe, których członkiem jest lub może zostać państwo lub partia - funkcję tego elementu pełnić może na przykład 
uczestnictwo szkoły w europejskiej sieci współpracy, programie wymiany uczniowskiej itp.

Jeśli powyższa analogia zostanie uznana za uprawnioną, to zasadne stanie się pytanie o szkolną kulturę polityczną. Idąc dalej tym tokiem myślenia, by zdefiniować kulturę polityczną szkoły, należy odnieść się do gotowej koncepcji kultury politycznej. Znajdziemy ich bardzo wiele i z pewnością nie każda da się zastosować do specyfiki szkolnej. Dokonując przeglądu literatury, zauważyć można, że współcześnie tworzone koncepcje kultury politycznej są nawiązaniem, próbą reinterpretacji czy operacjonalizacji koncepcji klasycznych. Sięgając do ich źródeł, analizie należy poddać koncepcje stworzone przez klasyków: Gabriela Almonda we współpracy z Binghamem G. Powellem (1975) i Sidneyem Verbą (1963), oraz Vilfreda Pareta (1935/2017), który - choć pisał o typach myślenia politycznego, nie zaś wprost o samej kulturze politycznej - w tym nurcie myślenia może być interpretowany (por. Bäcker, 2005). Biorąc pod uwagę fakt, że kultura polityczna, nie pozostaje obojętna wobec szerszego kontekstu kulturowego danego kraju, warto zwrócić uwagę także na koncepcje rodzime. W tej kategorii bezsprzecznie najszerzej koncepcje kultury politycznej rozwinął Zbigniew Blok (2005; 2009).

Znalezienie odpowiedniej dla specyfiki szkoły koncepcji kultury politycznej wymagało opracowania kryteriów, jakie powinny zostać przez tę koncepcję spełnione. Pomogły one znaleźć taką, która może zostać poddana dalszej adaptacji i zastosowana do rozważań nad szkołą jako organizacją o określonych właściwościach. Tymi kryteriami są warunki:

1) ogólności: wybrana koncepcja powinna tak interpretować ustrój polityczny, by dał się zaadoptować do systemu organizacyjnego szkoły lub po prostu uwzględniał możliwość zastosowania na poziomach niższych niż państwo-naród;

2) szczegółowości: wybrana koncepcja powinna obejmować pełen zakres możliwych przejawów kultury politycznej (subiektywnych i obiektywnych, materialnych i niematerialnych) oraz dostrzegać związki między nimi;

3) specyfikacji: wybrana koncepcja powinna wskazywać konkretne elementy kultury politycznej i posiadać kryteria rozróżniania (ale nie wartościowania) poszczególnych typów kultury politycznej, uwzględniając inne niż demokratyczny ustroje;

4) relacji dwukierunkowej: wybrana koncepcja powinna zauważać wpływ kultury politycznej na struktury polityczne oraz wpływ struktur politycznych na kulturę polityczną;

5) relacyjności: wybrana koncepcja powinna uwzględniać miejsce i relacje kultury politycznej w kulturze ogólnej; 
6) operacjonalizacji: wybrana koncepcja powinna dawać możliwość empirycznego zastosowania.

Każdej koncepcji należy zadać jednakowe pytania badawcze, aby sprawdzić, czy spełnia powyższe warunki:

1) w jakich kategoriach opisuje kulturę polityczną?

2) jakie dostrzega determinanty kultury politycznej?

3) jaka jest funkcja kultury politycznej?

4) w jakiej relacji do kultury ogólnej pozostaje kultura polityczna?

5) jaką typologię kultur politycznych proponuje?

6) jakie wprowadza kryteria ich weryfikacji?

Wybrana koncepcja pozwoli określić zakres przedmiotu badań, który zostanie zaadoptowany do specyfiki szkolnej. Tym samym pozwoli stworzyć definicję szkolnej kultury politycznej, a dzięki warunkowi operacjonalizacji umożliwi także opracowanie narzędzia badawczego do klasyfikacji jej typów. Poniżej zaprezentowano kolejno wyniki przeprowadzonej analizy dla koncepcji: Gabriela Almonda we współpracy z Binghamem G. Powellem (1975) oraz Sidneyem Verbą (1963), Vilfreda Pareto (1935/ 2017) w interpretacji Romana Bäckera (2005) oraz Zbigniewa Bloka $(2005 ; 2009)$.

\section{Koncepcja kultury politycznej Gabriela Almonda, Binghama G. Powella i Sidneya Verby}

\section{1) W jakich kategoriach opisana jest kultura polityczna?}

W rozumieniu autorów kultura polityczna to „psychologiczne orientacje w stosunku do społecznych obiektów” (Almond, Verba, 1963: 14). Przedmiotem badań nad kulturą polityczną są tu więc postawy członków danego systemu politycznego wobec obiektów politycznych (Almond, Powel, 1966: 53). Postawy i orientacje polityczne tworzą potencjalne możliwości polityczne, skłonności do określonego zachowania się i przez to wpływają na funkcjonowanie samego systemu politycznego (Sobolewski, 2001: 130).

\section{2) Jakie są determinanty kultury politycznej?}

Autorzy zwracają uwagę przede wszystkim na determinanty wewnętrzne. Wskazują trzy podstawowe elementy postawy: wiedzę, emocje i oceny. Zróżnicowane orientacje: poznawcza (zależna od posiadanej wiedzy), oceniająca (odnosząca się do systemu wartości) i afektywna (bazująca na własnych emocjach) - impli- 
kują różne zachowania jednostek w tych samych rolach w systemie politycznym (Almond, Powel, 1975: 577). Indywidualne wiedza, emocje i oceny tworzą możliwości polityczne, skłonności do określonego zachowania się i przez to wpływają na funkcjonowanie samego systemu politycznego (Sobolewski, 2001: 130). Jednocześnie zależą od oddziaływania tego systemu: posiadana wiedza bierze się z nauki i doświadczeń, oceny bazują na zinternalizowanym systemie wartości przekazywanym $\mathrm{w}$ najbliższym środowisku, $\mathrm{w}$ panującej ideologii czy w przekazie medialnym.

\section{3) Jaka jest funkcja kultury politycznej?}

W swoich pracach autorzy nie kryli aprobaty dla demokratycznych rządów. Jako cel stawiali sobie opisanie postaw korzystnych dla systemu demokratycznego, odnosząc się do centralnego kryterium szeroko rozumianej postawy partycypacyjnej. W swoich badaniach, biorąc pod uwagę tylko społeczności demokratyczne, tworzyli model idealny - kulturę obywatelską - wskazując na taką jej funkcję, jak podtrzymywanie i rozwój demokracji. Zwracali uwagę na zależność dwukierunkową typu kultury politycznej od panującego systemu politycznego oraz stabilności panującego systemu politycznego od dominującego typu kultury politycznej (Sobolewski, 2001: 130).

\section{4) W jakiej relacji do kultury ogólnej pozostaje kultura polityczna?}

W pismach Almonda i współautorów trudno znaleźć wnikliwe i dogłębne rozważania nad tym, czym jest polityka. Zakładają oni raczej jej potoczne rozumienie apriori.

Odróżnienie między kulturą polityczną a bardziej ogólnym systemem kultury społeczeństwa jest analityczne. Polityczna kultura jest integralnym aspektem kultury bardziej ogólnej, a system politycznych przekonań jednostki jest tylko częścią całości jego przekonań. Co więcej, podstawowe przekonania i wzory wartości kultury, które nie mają odniesienia do szczególnych politycznych obiektów - zwykle odgrywają istotną rolę w tworzeniu kultury politycznej. (Verba, 1956: 521)

Kultura polityczna postrzegana jest w perspektywie antropologicznej jako wyodrębniona część kultury ogólnej. Przymiotnik „polityczna” zawęża po prostu pole badań (całej kultury) do jej zakresu obejmującego stosunki polityczne społeczności, eliminując, dla celów badań, inne niepolityczne aspekty kultury danej grupy. 


\section{5) Jaką typologię kultur politycznych proponuje koncepcja?}

Na podstawie prowadzonych badań autorzy wyodrębnili trzy typy idealne kultury politycznej:

- zaściankowa. Charakteryzuje się małym zainteresowaniem zagadnieniami politycznymi i małą aktywnością polityczną - uznaną za postawę właściwą względem systemu politycznego. Społeczeństwo nie przypisuje sobie żadnej roli w procesach politycznych, nie dostrzega także znaczenia, jakie polityka ma dla życia jednostek. Zaściankowa kultura polityczna jest zamknięta na kontakty ze światem zewnętrznym, często opiera się na stereotypach;

- podporządkowana. Charakteryzuje się uległością rządzonych wobec rządzących. Społeczeństwo, pomimo że ma wiedzę na temat podmiotów politycznych i świadomość swojego znaczenia w systemie, nie dostrzega potrzeby angażowania się w politykę, uznając, że zadanie to należy do elity władzy. Charakteryzuje się biernością w kształtowaniu życia publicznego, brakiem zrozumienia tego, jak procesy polityczne wpływają na życie jednostek;

- uczestnicząca. Charakteryzuje społeczeństwo, w którym istnieją ukształtowane i ustabilizowane przekonania na temat roli polityki w modelowaniu życia poszczególnych grup i jednostek. Społeczeństwo cechuje duża aktywność społeczna, świadomość możliwości, jakie niesie aktywny udział w życiu politycznym (Almond, Verba, 1963).

Kultura polityczna danego społeczeństwa jest w rzeczywistości zawsze przemieszaniem różnych typów - o ogólnej ocenie decyduje typ dominujący. Opisana przez autorów kultura obywatelska (civic culture) jest typem mieszanym z przewagą dominacji kultury uczestniczącej i zachowanymi włączonymi w nią elementami typów kultury podporządkowanej i zaściankowej. Jest to typ kultury najbliższy ideałowi, charakterystyczny dla systemów amerykańskich i brytyjskich (Wiatr, 1999).

\section{6) Jakie sq kryteria weryfikacji w badaniach typów kultury politycznej?}

Almond i Verba przeprowadzili szerokie badania porównawcze postaw politycznych ludności pięciu krajów: Stanów Zjednoczonych, Wielkiej Brytanii, Niemiec, Włoch i Meksyku. W studium Civic Culture, Political Attitudes and Democracy in Five Nations wymieniali pytania, na jakie należy odpowiedzieć, by opisać i scharakteryzować kulturę polityczną danej grupy społecznej: 
- co uczestnicy wiedzą na temat swojego narodu, systemu politycznego, historii, jaki jest ich stosunek emocjonalny do narodu?

- co uczestnicy wiedzą o instytucjach politycznych, o grze politycznej, przywódcach, jakie żywią wobec nich uczucia?

- co uczestnicy wiedzą o mechanizmach polityki, o procesach podejmowania decyzji politycznych, jak postrzegają ważne wydarzenia polityczne, na przykład wybory, jak je oceniają?

- jak uczestnik widzi swoją osobę i położenie w systemie politycznym, jakie emocje towarzyszą kontaktom z systemem? (Almond, Verba, 1963: 50).

Współcześnie koncepcji tej zarzuca się jednak „przeterminowanie się” wartości eksplanacyjnej. Zaproponowane przez Almonda i Verbę badania bazowały na porównywaniu typu pożądanego kultury obywatelskiej oraz jej dwóch ułomnych wersji: podporządkowanej i zaściankowej. Obracając się cały czas w kręgu społeczeństw demokratycznych, autorzy w badaniach oceniali ich oddalenie od ideału. Współcześnie trudno jest jednak zaobserwować społeczności demokratyczne o typach dominujących zaściankowym lub poddańczym. Koncepcja ta nie daje już więc możliwości empirycznego zastosowania w badaniach porównawczych (Blok, Pająk-Patkowska, 2016: 26).

\section{Typy myślenia społecznego Vilfreda Pareta a typologia kultur politycznych}

Poniżej opisana koncepcja typologii kultur politycznych została stworzona przez Romana Bäckera (2005) na podstawie zmodyfikowanej typologii myśli politycznej wywodzącej się z klasyfikacji typów myślenia społecznego opisanych przez Vilfreda Pareta (1994).

\section{1) W jakich kategoriach opisana jest kultura polityczna?}

Typy myślenia społecznego Pareto wyprowadza z trzech sposobów komunikowania się między ludźmi:

- komunikacja dla wiedzy: oparta na logice analitycznej i weryfikowalności twierdzeń lub w swojej antynomii na quasi-nauce bez dbania o logikę i rzetelność ostatecznych rezultatów wywodu. Celem tego myślenia społecznego jest tworzenie modelu prawdy, dostarczenie poczucia pewności i trwałości;

- komunikacja dla zaspokojenia residuów (Pareto, 1994: 165), własnych potrzeb i aspiracji. Realizuje się ona poprzez myślenie mityczne wytwarzające derywacje, czyli przekonania i sądy, które mają pozwolić na jednoczesne 
realizowanie residuów i podtrzymanie więzi społecznych. Realizowania własnych potrzeb w sposób akceptowalny przez grupę społeczną. Myślenie mityczne pozwala zaspokoić potrzeby bezpieczeństwa i tożsamości. Może przyjmować formę religii, ideologii lub myślenia plemiennego (współcześnie postplemiennego) (Bäcker, 2005: 98-99);

- komunikacja z potrzeby więzi społecznej. Realizuje się ona w myśleniu komunikacyjnym określanym jako „bla bla” lub plotki. Celem jest tu wyłącznie zaspokojenie potrzeby przynależności poprzez podtrzymanie więzi społecznych. Antynomią myślenia komunikacyjnego jest myślenie wegetatywne, gdzie jedynym celem jednostki jest bezpośrednie i jak najszybsze zaspokojenie własnych potrzeb życiowych, najczęściej biologicznych (Pareto, 1994).

Każdy z powyższych typów myślenia łączy się z wzorcem osobowościowym. Roman Bäcker wyprowadza z nich typ myślenia politycznego i typy kultury politycznej. Myślenie polityczne ma tu charakter świadomościowy, pełni funkcję buforu. Kulturę polityczną zaś możemy opisywać w kategorii działania - reakcji na bodziec polityczny - zależnej od charakterystyki tego buforu, jakim jest myślenie polityczne Przedmiotem badań nad kulturą polityczną byłyby więc obserwowalne działania: jednostek, grup, partii, rządzących i rządzonych, a nie ich deklaracje.

\section{2) Jakie sq determinanty kultury politycznej?}

Typ kultury politycznej jest zdeterminowany sposobami myślenia społecznego i wzorcami osobowościowymi, pozostając z nimi kompatybilnym w taki sposób, że wzorzec osobowy człowieka wpływa na jego typ myślenia społecznego, co implikuje typ kultury politycznej, jaki przedstawia (Bäcker, 2005: 102). Pareto pokazuje, jak silne i nieracjonalne są motywy działań społecznych. Wprowadza pojęcie residuów jako odwiecznych dyspozycji motywacyjnych istniejących w naturze ludzkiej i zakorzenionych w instynktach, emocjach oraz namiętnościach obecnych nawet w wysoce abstrakcyjnych, tworzonych przez „,czysty” intelekt teoriach (Pareto, 1994: 165). Każda struktura polityczna propaguje przy tym konkretne wzorce osobowościowe, jednak efektywność ich przejmowania przez jednostki zależna jest od predyspozycji indywidualnych (Bäcker, 2005: 101).

\section{3) Jaka jest funkcja kultury politycznej?}

W interpretacji Romana Bäckera kultura polityczna jest ogniwem, które spaja cechy osobowościowe i odpowiadający im typ myślenia społecznego ze światem wiedzy, uczuć i woli politycznej (Bäcker, 2005: 102). 


\section{4) W jakiej relacji do kultury ogólnej pozostaje kultura polityczna?}

Pareto opisuje typy myślenia społecznego, które opiera na sposobach komunikowania się między ludźmi, zdeterminowane przez trzy kryteria: wiedzę, chęć zaspokojenia własnych potrzeb i aspiracji oraz potrzebę więzi społecznej (Pareto, 1994: 165). Z takiego ogólnego ujęcia, opartego na pewnych charakterystycznych cechach natury ludzkiej, Roman Bäcker wyprowadził najpierw typy myślenia politycznego, a następnie typy kultur politycznych. Typ kultury politycznej jest więc kompatybilny z szerszym kontekstem, $\mathrm{z}$ danym typem myślenia oraz z wzorcem osobowości, który determinuje wszystkie sfery społecznego działania, nie tylko polityczną. Warto zauważyć także, że typologia Pareta i Bäckera jest niezależna od systemu demokratycznego. Część opisanych typów kultury politycznej charakterystyczna jest dla niedemokratycznych społeczeństw/grup, część może przejawiać się zarówno w demokratycznych, jak i niedemokratycznych systemach.

\section{5) Jaką typologię kultur politycznych proponuje koncepcja?}

Analizując koncepcje Vilfreda Pareta, Roman Bäcker wyprowadza z niej następujące typy kultury politycznej:

- wegetatywny. Jednostka o tym typie kultury postrzega świat tylko przez pryzmat własnych korzyści i strat, nie biorąc pod uwagę możliwych konsekwencji. Cechuje się wysokim poziomem konformizmu i brakiem zasad. Jest zdolna do wszystkich działań, które w danym momencie uzna za pożyteczne dla siebie. W systemach demokratycznych jednostka taka będzie prezentować postawę wycofania, jednakże może łatwo aktywizować się, zachęcona materialnymi korzyściami. W systemach totalitarnych jednostka będzie aktywnie (biurokratycznie) podporządkowana, nie wykazując żadnych zachowań buntowniczych (Bäcker, 2005: 102-103);

- posttrybalny. Jednostki o tym typie kultury dążą do realizacji grupowych korzyści kosztem otoczenia społecznego. Normy społeczne traktują relatywnie w zależności od tego, czy dotyczą one „swoich”, czy „obcych”. Jest to typ, który może wystąpić we wszystkich rodzajach systemów politycznych, najczęściej jednak w autorytarnych strukturach władzy (częściej na poziomie lokalnym niż narodowym) (Bäcker, 2005: 103);

- trybalny. Jednostki o tym typie kultury odporne są na działanie procesów modernizacyjnych. Opierają się na przekazywanych pokoleniowo wzorach postępowania wobec i w ramach struktur władzy, zarówno wewnątrz danej grupy, jak i na zewnątrz. Przekazywane rytuały bazują na biało-czarnych, 
schematycznych wyobrażeniach o świecie. Jest to typ prezentowany w XX wieku przez mafię włoską (Bäcker, 2005: 103);

- zracjonalizowano-mityczny. Jednostki o tym typie kultury charakteryzują się umiejętnością łączenia interesów indywidualnych z grupowymi. Podejmują próby ich jednoczesnego realizowania. Kultura ta oparta jest na jednoczesnym myśleniu ideologicznym lub religijnym i logice arystotelesowskiej. Warunkiem podstawowym jest tu postawa tolerancji, uznanie odmienności i prawa do podmiotowości innych osób. Walka polityczna postrzegana jest jako gra o wyniku zero-jedynkowym. Jest to kultura charakterystyczna dla społeczeństwa otwartego (Popper, 1987). Porównywana może być z kulturą obywatelską społeczeństwa demokratycznego (Bäcker, 2005: 103-104);

- fundamentalistyczny. Jest to kultura społeczności, która w gwałtownie zmieniającym się, modernizującym się społeczeństwie dąży do utrzymania tradycyjnych wzorców życia społecznego. Ten typ kultury ma charakter kontrkulturacyjny, niekiedy natywistyczny. Powstaje pod silnym wpływem współczesnych derywacji wykorzystujących na przykład zasoby frazeologiczne religii uniwersalistycznych czy też tradycyjne wzorce zachowań politycznych (Bäcker, 2005: 104);

- totalitarny. Jej rdzeniem jest gnoza polityczna. Jednostka o takim typie kultury wzrasta najlepiej w kontekście kultury wegetatywnej lub posttrybalnej. Charakteryzuje się rewolucjonistycznym lub hiperaktywistycznym wzorcem osobowości (Bäcker, 2005: 104).

\section{6) Jakie sqa kryteria weryfikacji w badaniach typów kultury politycznej?}

Dla koncepcji socjologicznej Vilfreda Pareta właściwa jest metoda obserwacji zachowań, aktywności i działań będących przedmiotem badań nad kulturą polityczną. Niektórzy autorzy zauważają jednakże w niej pewne niejasności, dotyczące definiowania residuów tak istotnych w kwalifikacji typów myślenia społecznego i typów kultury politycznej. W dziele Pareta znajdziemy wiele niespójnych interpretacji tego pojęcia. W jednym miejscu utożsamia je z instynktem (Pareto, 1994: 165), w innym z uczuciem (Pareto, 1994: 204). Jednocześnie twierdzi, że residua co prawda są pośrednio związane z uczuciami i instynktem, ale jednocześnie są czymś innym, bo to „uczucia wyrażane są poprzez rezydua” (Pareto, 1994: 169). Wyjaśniając przyczyny obserwowalnych zachowań, nie możemy zatem odnieść się do obiektywnie poznawalnych elementów rzeczywistości, a jedynie do intuicyjnych kategoryzacji. Pareto tłumaczy każde działanie (a więc także działanie poli- 
tyczne) odpowiednią kombinacją residuów. Jeśli zatem nie mamy spójnej definicji residuów, nie mamy w istocie możliwości weryfikacji koncepcji tego autora (Szczepański, 1961: 298).

\section{Koncepcja kultury politycznej Zbigniewa Bloka}

\section{1) W jakich kategoriach opisana jest kultura polityczna?}

Kultura polityczna traktowana jest w koncepcji Zbigniewa Bloka jako filtr modyfikujący różne systemowe bodźce, takie jak przymus, autorytet, manipulacja, propaganda czy reklama, i prowadzący do konkretnych zachowań politycznych będących przedmiotem obserwacji badacza. Należy zatem do sfery świadomościowej. Jest częścią świadomości społecznej, świadomości jednostkowej, która pozwala na eliminowanie, porządkowanie według ważności czy modyfikowanie swoich zachowań oraz decyzji politycznych oraz modelowanie ról społecznych/ politycznych zarówno rządzących, jak i rządzonych (Blok, 2005: 52).

\section{2) Jakie sq̨ determinanty kultury politycznej?}

Autor wyróżnia cztery bazowe moduły struktury świadomości wchodzące w zakres kultury politycznej. Są to:

- idee, wartości i normy polityczne - zinternalizowane i podzielane oraz świadomie odrzucone;

- nawyki, tradycje i wzory polityczne, wspomagające system polityczny i niewspomagające systemu politycznego;

- emocje wobec podmiotów i przedmiotów polityki - pozytywne i negatywne;

- kryteria oceny faktów, zjawisk i procesów politycznych, preferujące interes całości społeczeństwa, grupy społecznej i jednostki (Blok, 2005: 53).

Określanie typu kultury politycznej jednostki to ustalenie, w jakim miejscu znajduje się jednostka $\mathrm{w}$ rozpisanej przestrzeni skrajnych determinantów dla każdej z tych płaszczyzn. Miejsce to zależne jest od zinternalizowanych wartości, norm i idei, przeżytych doświadczeń życiowych, doświadczanych uwarunkowań historycznych, warunków klimatyczno-geograficznych czy ekonomicznych życia.

\section{3) Jaka jest funkcja kultury politycznej?}

Ten sam bodziec polityczny w zależności od charakteru filtra spowoduje odmienne reakcje. Oddziaływanie bodźca generuje więc pewną pulę możliwych zachowań politycznych i możliwych sposobów myślenia o polityce. Z tego zbioru tylko nie- 
które możliwe reakcje przepuszczane są przez filtr „kultury politycznej”, zależnej od charakteru filtra. Zachowania uznane za niepożądane, niestosowne, niegodne itp. są eliminowane. Następnie te, które przechodzą, zostają uporządkowane według wyznaczanej przez charakter filtra hierarchii ważności (Blok, 2009: 100). Funkcją kultury politycznej jest więc „wyeliminować, zmodyfikować lub uporządkować zachowania polityczne oraz decyzje" (Blok, 2009: 101).

\section{4) W jakiej relacji do kultury ogólnej pozostaje kultura polityczna?}

Autor nie odwołuje się wprost do korelacji kultury politycznej z kulturą ogólną. Przywołuje definicje kultury Antoniny Kłoskowskiej. Ujmuje ona kulturę jako wieloaspektową całość, w której wyróżnić możemy warstwę:

- zinternalizowanych norm, wzorów i wartości tkwiącą w świadomości ludzi;

- działań będących wyrazem zinternalizowanych norm wzorów i wartości;

- wytworów i obiektów stających się przedmiotem kulturowych działań;

- typów myślowych, na przykład język (Kłoskowska, 1981: 108-117).

Zbigniew Blok wielokrotnie podkreśla możliwość poszerzania wymienionego zakresu determinant kultury politycznej postrzeganej, zdaje się, jako zinternalizowana warstwa świadomości ludzi wywodząca się z kultury ogólnej (Blok, 2009: 89).

\section{5) Jaką typologię kultur politycznych proponuje koncepcja?}

Autor operacjonalizuje każdy z czterech elementów składowych świadomości, określając i definiując cztery podstawowe moduły kultury politycznej i wyznaczając dla każdego z nich punkty skrajne - wymiary. W ten sposób w module pierwszym, tworzonym przez idee, wartości i normy polityczne, wyróżnić można wymiary:

- indywidualizm-kolektywizm (prymat dobra jednostki nad dobrem grupy i odwrotnie);

- wolność-równość (prymat swobody działania lub prymat równego traktowania);

- sprawiedliwość-niesprawiedliwość (traktowanie innych ludzi w taki sam sposób na podstawie takich samym kryteriów moralnych lub traktowanie różnych ludzi w różny sposób na podstawie przypadkowych kryteriów).

Moduł drugi tworzą nawyki, tradycje i wzory polityczne. Proponowane przez autora wymiary dla tego modułu to:

- demokracja-totalitaryzm (stosunek obywateli do rozwiązań demokratycznych);

- tolerancja-nietolerancja (postrzeganie odmienności i stosunek do obcych);

- elitaryzm-egalitaryzm (stosunek do hierarchii w strukturach społecznych). 
Moduł trzeci to emocje wobec polityki, tworzą go wymiary:

- zgoda-walka (postawa ugodowa postrzegana jako ważne dobro społeczne kontra nastawienie rywalizacyjne, dążenie do konfrontacji);

- patriotyzm-kosmopolityzm (przywiązanie do własnego państwa lub jego brak i poczucie przynależności do szerszej wspólnoty);

- fundamentalizm-nihilizm (opieranie się na zakotwiczonych w świadomości ideach kontra całkowity relatywizm wartości i idei);

- woluntaryzm-fatalizm (postrzeganie decyzyjnego wpływu podmiotu na kształt dziejów lub jego brak);

- pesymizm-optymizm (postrzeganie przebiegu wydarzeń w sposób negatywny lub pozytywny).

Ostatni moduł (czwarty) tworzą oceny polityki, czyli stosowane przez społeczeństwo kryteria oceny działań podmiotów politycznych. Możemy wyróżnić tu wymiary:

- sprawiedliwe-niesprawiedliwe (działania przestrzegające kryteriów oceniania lub je łamiące);

- efektywne-skuteczne (działania osiągające efekt przy najmniejszych kosztach lub działania osiągające efekt bez względu na koszty);

- zobiektywizowane-uznaniowe (ocena na podstawie jasno określonych lub przypadkowych kryteriów);

- racjonalne-irracjonalne (ocena oparta na precyzyjnych kryteriach versus ocena zależna od stanu emocjonalnego jednostki) (Blok, 2005: 116-118).

$\mathrm{Z}$ tak zoperacjonalizowanych pojęć Blok tworzy mapę typologii kultury politycznej, pozwalającą umieścić indywidualnie każdą jednostkę na 10-punktowej skali między skrajnościami każdego z wymiarów wszystkich założonych modułów. Daje też możliwość wyliczenia średniej istotnej dla określenia typu dominującego. Autor uwzględnia możliwość dalszej empirycznej rozbudowy pojęcia kultury politycznej o kolejne moduły (na przykład postawy wobec aktywności politycznej), jak również pogłębionej analizy tylko jednego wybranego przez badacza wymiaru. Dodatkowo każdy z modułów może być rozbudowany o kolejne dychotomie w zależności od przyjętych założeń metodologicznych i teoretycznych. Dzięki czemu badacz może sam poszerzać siatkę typologiczną, jednakże zawsze w pewnym sztywnym, sprawdzalnym schemacie.

\section{6) Jakie są kryteria weryfikacji w badaniach typów kultury politycznej?}

Koncepcja omawia dokładnie kolejne etapy operacjonalizacji i weryfikacji: precyzyjne zdefiniowanie modułów kultury i dychotomicznych pojęć, przełożenie ich na język zrozumiały dla osób badanych, zapisując je w formie opiso- 
wego przedstawienia krańców danej skali, przeprowadzenie badań pilotażowych, zebranie danych z badań właściwych. Na podstawie zaproponowanych badań empirycznych można ustalić, w jakim miejscu w przestrzeni skrajnych czynników determinujących moduły kultury znajduje się jednostka. Według wyprowadzonego wzoru można określić jej zindywidualizowany typ kultury politycznej. Dopiero wówczas, mając ustalone, kto jest nośnikiem kultury politycznej i w jakim czasie można dokonywać uogólnień, tworzy się typy idealne czy modele.

Tabela 1. Porównanie analizowanych koncepcji kultury politycznej zgodnie z postawionymi pytaniami analitycznymi

\begin{tabular}{|c|c|c|c|}
\hline Kryteria analizy & G. Almond & V. Parero & Z. Blok \\
\hline $\begin{array}{l}\text { Kategorie } \\
\text { opisu kultury } \\
\text { politycznej }\end{array}$ & $\begin{array}{l}\text { psychologiczna orientacja; } \\
\text { przedmiot badań: } \\
\text { postawy. }\end{array}$ & $\begin{array}{l}\text { reakcja na bodziec } \\
\text { polityczny; } \\
\text { przedmiot badań: } \\
\text { działania/zachowania. }\end{array}$ & $\begin{array}{l}\text { filtr między bodźcem } \\
\text { a reakcją; } \\
\text { przedmiot badań: } \\
\text { zachowania. }\end{array}$ \\
\hline $\begin{array}{l}\text { Determinanty } \\
\text { kultury } \\
\text { politycznej }\end{array}$ & wiedza, emocje, oceny. & $\begin{array}{l}\text { wzorzec osobowy + typ } \\
\text { myślenia społecznego. }\end{array}$ & $\begin{array}{l}\text { - idee, wartości normy, } \\
\text { - nawyki, tradycje, } \\
\text { wzory, } \\
\text { - emocje, } \\
\text { - kryteria oceny. }\end{array}$ \\
\hline $\begin{array}{l}\text { Funkcje kultury } \\
\text { politycznej }\end{array}$ & $\begin{array}{l}\text { podtrzymanie i rozwój } \\
\text { demokracji. }\end{array}$ & $\begin{array}{l}\text { ogniwo spajające cechy } \\
\text { osobowościowe, typ } \\
\text { myślenia społecznego } \\
\text { i świat polityki. }\end{array}$ & $\begin{array}{l}\text { eliminowanie, } \\
\text { porządkowanie, } \\
\text { modyfikowanie zachowań } \\
\text { i decyzji politycznych. }\end{array}$ \\
\hline $\begin{array}{l}\text { Relacja kultury } \\
\text { politycznej do } \\
\text { kultury ogólnej }\end{array}$ & $\begin{array}{l}\text { kultura polityczna jako } \\
\text { wyodrębniona (zawężona) } \\
\text { część kultury ogólnej. }\end{array}$ & $\begin{array}{l}\text { kultura polityczna } \\
\text { to jeden z aspektów } \\
\text { szerszego kontekstu } \\
\text { działań społecznych } \\
\text { determinowanych przez } \\
\text { wzorzec osobowy i typ } \\
\text { myślenia. }\end{array}$ & $\begin{array}{l}\text { kultura polityczna } \\
\text { wywodzi się z kultury } \\
\text { ogólnej. }\end{array}$ \\
\hline $\begin{array}{l}\text { Typologia } \\
\text { kultury } \\
\text { politycznej }\end{array}$ & $\begin{array}{l}\text { - zaściankowa, } \\
\text { - podporządkowana, } \\
\text { - uczestnicząca. } \\
\text { * typologia stworzona } \\
\text { do badań systemów } \\
\text { demokratycznych } \\
\text { pozwala określać } \\
\text { odległość kultury } \\
\text { dominującej od ideału } \\
\text { partycypacyjnego. }\end{array}$ & $\begin{array}{l}\text { - wegetatywna, } \\
\text { - posttrybalna, } \\
\text { - trybalna, } \\
\text { - zracjonalizowano- } \\
\text { mityczna, } \\
\text { - fundamentalizmu, } \\
\text { - totalitarna. } \\
\text { * typologia obejmuje } \\
\text { systemy demokratyczne } \\
\text { i niedemokratyczne. }\end{array}$ & $\begin{array}{l}\text { typologia przedstawiona } \\
\text { w przestrzeniach } \\
\text { skrajnych czynników } \\
\text { determinujących } \\
\text { poszczególne moduły } \\
\text { i ich zakresy jest } \\
\text { precyzyjna, ale otwarta } \\
\text { i zindywidualizowana. } \\
\text { × nie ma powiązania } \\
\text { z systemami politycznymi. }\end{array}$ \\
\hline
\end{tabular}




\begin{tabular}{|l|l|l|l|}
\hline $\begin{array}{l}\text { Kryteria } \\
\text { weryfikacji }\end{array}$ & $\begin{array}{l}\text { wywiady dotyczące } \\
\text { wiedzy, emocji i ocen } \\
\text { respondentów; badania } \\
\text { porównawcze. }\end{array}$ & $\begin{array}{l}\text { obserwacja zachowań/ } \\
\text { działań/aktywności }\end{array}$ & $\begin{array}{l}\text { kwestionariusz } \\
\text { samooceny w ramach } \\
\text { podstawowych czterech } \\
\text { modułów świadomości } \\
\text { na 10-stopniowej skali + } \\
\text { obserwacja zachowań. }\end{array}$ \\
\hline
\end{tabular}

Źródło: opracowanie własne

Podsumowując dokonaną analizę oraz zestawienie przedstawione $\mathrm{w}$ tabeli, można stwierdzić, co następuje. Warunek pierwszy: ogólności, czyli takiej interpretacji systemu politycznego, by dał się zastosować na poziomie niższym niż państwo-naród, spełniają koncepcje Bloka i Pareta. Koncepcja Pareta wyjściowo dotyczyła myślenia społecznego, co może ułatwiać jej zastosowanie w przestrzeni szkolnej, korzystając z adaptacji Romana Bäckera dla tych wymiarów życia społecznego, które mają charakter polityczny (zgodnie z funkcją kultury politycznej jako spoiwa). Koncepcja Bloka, ze względu na otwartość schematu typologii dla indywidualnego badacza, dopuszcza mówienie o kulturze politycznej na różnych poziomach złożoności społecznej: grupy społecznej, narodu, społeczeństw złożonych zależnie od przyjętych założeń teoretycznych i metodologicznych.

Wszystkie trzy koncepcje spełniają warunek szczegółowości, obejmując cały zakres wszelkich możliwych przejawów kultury politycznej. Kryteria rozróżniania poszczególnych typów kultury są w nich antynomiczne. Przy czym w koncepcji Pareta brak jest jasności definicji, przede wszystkim wprowadzonych przez autora residuów, które w różnych momentach tekstu mają inną interpretację. Takie rozmycie definicyjne będzie z pewnością przeszkodą w adaptacji koncepcji do warunków szkolnych. Klasyfikacje Almonada oraz Bloka oparte są na rozłącznych, biegunowo zdefiniowanych typach idealnych (Almond) czy też skrajnych (Blok). Warto przytoczyć jednak zarzut kierowany do koncepcji stworzonej przez Almonda jako odwołującej się tylko do systemów demokratycznych, nieobejmującej zachowań politycznych innych społeczności, szczególnie spoza kręgu społeczeństw kultury łacińskiej (Bäcker, 2005: 97).

Wszystkie koncepcje spełniają warunek relacyjności i biorą pod uwagę warunek relacji dwukierunkowej (uwzględniając takie procesy, jak internalizacja, socjalizacja, doświadczenia życiowe: historyczne, społeczne czy gospodarcze), choć koncepcja Almonda zdaje się niedostatecznie uwzględniać możliwe procesy społeczne i psychologiczne zachodzące pomiędzy deklaracją postaw a faktycznym zachowaniem jednostek. Autor w swoich badaniach bierze pod uwage deklaracje, a nie działania. Wszystkie koncepcje wskazują na konkretne elemen- 
ty kultury politycznej i podają jej typy. Jednakże tylko koncepcja Bloka całkowicie unika warunku niewartościowania. Koncepcja Almonda jako wzorowy przedstawia typ kultury partycypacyjnej, określając oddalenie od niego pozostałych typów idealnych i faktycznych. Koncepcja Pareta sugeruje jako pożądany typ kultury racjonalno-mitycznej. Zarówno u Almonda, jak i u Pareta typy kultury politycznej mają charakter typów idealnych. Autorzy najpierw dokonali badań, a następnie na ich podstawie opracowali pewne typy idealne - modele kultury. Blok proponuje podejście odwrotne. Najpierw operacjonalizuje każdy z czterech elementów składowych świadomości kultury politycznej, wyznaczając na nich punkty skrajne. Następnie z tak zoperacjonalizowanych pojęć tworzy mapę typologii kultury politycznej, pozwalającą umiejscowić jednostkę między skrajnościami przypisanymi dla każdej kategorii, każdego elementu. W ten sposób mamy możliwość wydzielenia bardzo wielu typów kultury politycznej. Każdy jest zindywidualizowany oraz może być indywidualnie modyfikowany, rozszerzany przez badacza. Biorąc pod uwagę zakres oraz możliwość adaptacji do mniejszych społeczności i systemów ich politycznej organizacji (np. szkoły), pasująca wydaje się zarówno koncepcja Pareta (wraz z adaptacją Romana Bäckera), jak i Zbigniewa Bloka. Jednakże uwzględniając ostatni warunek - operacjonalizacji - należy wybrać koncepcję Zbigniewa Bloka, gdyż, jak wskazywano już powyżej, koncepcja Pareta niesie pewne utrudnienia interpretacyjne, przez co nie daje się precyzyjnie zoperacjonalizować.

W wyniku metaanalizy teoretycznej jako wiodącą - w najwyższym stopniu spełniającą wyznaczone kryteria - wybrano zatem koncepcję kultury politycznej Zbigniewa Bloka (2005; 2009). Daje ona możliwość indywidualnego określenia typu kultury politycznej każdej jednostki poprzez umiejscowienie jej na 10-punktowej skali każdego z wymiarów wszystkich założonych modułów wraz z możliwością wyliczenia średniej istotnej dla określenia typu dominującego. Nie bazuje na typach idealnych, dzięki czemu unika wartościowania. Takie podejście, dające precyzyjny i sztywny, ale otwarty schemat, sprawdzi się podczas adaptacji na różnych poziomach społecznej złożoności, której organizacja przybiera formę polityczną.

Autor koncepcji zaznacza istotną kwestię dotyczącą przejścia do etapu formułowania pojęć zrozumiałych dla osoby badanej. Proponuje konkretne formuły pytań wywiadu, zaleca badania pilotażowe mające na celu weryfikację rozumienia pojęć abstrakcyjnych. W kontekście zastosowania koncepcji kultury politycznej na poziomie szkoły kwestia ta przypomina o konieczności takiego sformułowania pytań wywiadu, aby wskazywały wyraźnie na stosunek do systemu szkolnego. I tak na przykład dla modułu pierwszego, który tworzą idee, wartości i normy polityczne, autor wyróżnia trzy podstawowe wymiary: 
- indywidualizm-kolektywizm, określający preferencję dobra jednostki nad dobrem ogółu i odwrotnie;

- wolność-równość, określający prymat wartości swobody działania nad równym traktowaniem i odwrotnie;

- sprawiedliwość-niesprawiedliwość, określający konieczność traktowania ludzi w taki sam sposób na podstawie jednakowych kryteriów lub w różny sposób na podstawie przypadkowych kryteriów.

Dla przedstawionych wymiarów stworzyć możemy, zgodnie z wytycznymi autora koncepcji, zrozumiałe dla badanych twierdzenia w formie opisowego przedstawienia krańców danej skali. Dla poziomu społeczności szkolnej mogłyby to być na przykład:

W mojej szkole najważniejsze jest dla mnie, bym mógł realizować własne pasje i dbać o swój interes (indywidualizm). W szkole należy pamiętać o dobru grup, do których należymy (klasa, koło zainteresowań), czasem trzeba zrezygnować $z$ własnych celów (kolektywizm).

Ważne jest dla mnie poczucie, że wszyscy uczniowie sa sprawiedliwie traktowani (sprawiedliwość). Nie jest dla mnie ważny sposób traktowania innych uczniów $z$ mojej szkoly (niesprawiedliwość).

W szkole najważniejsze jest, aby uczniowie mieli swobodę działania w różnych obszarach (wolność). W szkole najważniejsze jest, aby została zachowana równość $w$ różnych obszarach (równość).

I dalej podobnie dla kolejnych modułów, realizując sformułowane przez Marię Dudzikową założenie:

(...) kulturę szkoły stanowi zespół idei, poglądów, zasad i praktyk szkoły, które w jawny lub ukryty sposób oddziałują na rozwój osoby i zmianę społeczną, zarówno w czasoprzestrzeni szkoły, jak i w jej bezpośrednim i pośrednim otoczeniu. Na tak pojmowaną kulturę szkoły składają się kultury jej podmiotów powiązanych interakcyjnie: nauczycieli, uczniów, „niepedagogicznych” pracowników szkoły oraz rodziców. Swój niewątpliwy udział mają tu także zjawiska i procesy o zasięgu lokalnym, regionalnym i globalnym. (Dudzikowa, Bochno, 2016: 6)

\section{Bibliografia}

Almond G., Powell G.B. (1966), Comparative Politics: a Developmental Approach; an analytic study, Boston.

Almond G., Powell G.B. (1975), Kultura polityczna, [w:] W. Derczyński, A. Jasińska-Kania, J. Szacki (red.), Elementy teorii socjologicznych, Warszawa. 
Almond G., Verba S. (1963), The Civic Culture, Political Attitudes and Democracy in Five Nations, Princeton.

Bäcker R. (2005), Typy myślenia społecznego Vilfredo Pareto a typologia kultur politycznych, [w:] Z. Blok (red.), Teoretyczne i metodologiczne problemy badań nad kultura polityczną, Poznań.

Blok Z. (2009), O polityczności, polityce, politologii, Poznań.

Chmaj M., Żmigrodzki M. (1996), Wprowadzenie do teorii polityki, Lublin.

de Lazari A. (2016), Czy brak kultury też jest kulturą, [w:] A. Sarnacki (red.), Kultura polityczna jako przedmiot badań, Kraków.

Dernowska U., Tłuściak-Delikowska A. (2015), Kultura szkoły. Studium teoretyczno-empiryczne, Kraków.

Dymara B. (2009), Dziecko w świecie edukacji, Kraków.

Dudzikowa M., Bochno E. (2016), Wprowadzenie do serii „Kultura Szkoły”, [w:] M. Dudzikowa, S. Jaskulska (red.), Twierdza. Szkoła w metaforze militarnej. Co w zamian?, Warszawa.

Ferejohn J., Rakove J., Riley J. (2001), Constitutional Culture and Democratic Rule, Cambridge.

Kłoskowska A. (1981), Socjologia kultury, Warszawa.

Pareto V. (2017 [1935]), The Mind and Society, New York.

Podolak M., Żmigrodzki M. (2013), System polityczny i jego klasyfikacje, [w:] M. Żmigrodzki, B. Dziemidok-Olszewska (red.), Współczesne systemy polityczne, Warszawa.

Sarnacki A. (2016), Wstęp, [w:] A. Sarnacki (red.), Kultura polityczna jako przedmiot badań, Kraków.

Sobolewski M. (2001), Pisma nieznane i rozproszone, Kraków.

Szczepański J. (1961), Socjologia. Rozwój problematyki i metod, Warszawa.

Wiatr J.J. (1999), Socjologia polityki, Warszawa.

Wildawski A. (1995), Kulturowa teoria przywództwa, [w:] J. Szczupaczyński (wyb.), Władza i społeczeństwo. Antologia tekstów z socjologii polityki, Warszawa.

Verba S. (1965), Comparative political culture, [w:] L. Pye, S. Verba (red.), Political Culture and Political Development, New York.

Zieliński E. (1999), Nauka o państwie i polityce, Warszawa. 
